\title{
Microscopic Examination of Urine Samples as the Early Detection of Asymptomatic Urinary Tract Infection in Pregnant Women: A Cross-Sectional Study
}

\author{
Uji Mikroskopik Spesimen Urin sebagai Deteksi Dini Infeksi Saluran Kemih tidak \\ Bergejala pada Perempuan Hamil: Sebuah Studi Potong Lintang
}

\author{
Yeva Rosana ${ }^{1}$, Dwiana Ocviyanti' ${ }^{2}$, Rahmah Amran ${ }^{3}$ \\ ${ }^{1}$ Department of Microbiology \\ ${ }^{2}$ Department of Obstetrics and Gynecology \\ ${ }^{3}$ Faculty of Medicine Universitas Indonesia \\ Dr. Cipto Mangunkusumo General Hospital \\ Jakarta
}

\begin{abstract}
Objective : To investigate the role of microscopic examination of urine sample in supporting early diagnosis of asymptomatic Urinary Tract Infection (UTI) in pregnant women. To compare correspondence between microscopic examination and urine culture result as a gold standard diagnostic modality to support the diagnosis of UTIs and as an evidence-based to start empirical therapy.
\end{abstract}

Methods : Microscopic analysis was conducted in 74 centrifuged and non-centrifuged urine samples from 317 pregnant who came to six healthcare centres in Jakarta, which showed a positive result of nitrite examination. The results of the microscopic examination of bacteriuria and leukocyturia were compared with a urine culture.

Results : Sensitivity of centrifuged bacteriuria was the highest among the other microscopic parameters, which was $74 \%$ with the $p$-value of 0.009 . Combination of bacteriuria and leukocyturia $\geq 3 / \mathrm{HPF}$ dan $\geq 5 / \mathrm{HPF}$ have increased the specificity with the value of $91.5 \%$ and $93.6 \%$ in noncentrifuged urine.

Conclusions : This result showed that the best method of microscopic examination for early diagnosis of asymptomatic urinary tract infection in pregnant women is the detection of bacteriuria in centrifuged urine. Combination of bacteriuria and leukocyturia test, as well as leukocyturia $\geq 3 / \mathrm{HPF}$ and $\geq 5$ / HPF, can be used to rule out the diagnosis of UTI at an early stage.

Keywords : asymptomatic urinary tract infection, bacteriuria, leukocyturia,microscopic examination, urine culture.

\begin{abstract}
Abstrak
Tujuan: Mengetahuiperan pemeriksaan mikroskopis sampel urin dalam mendukung diagnosis dini Infeksi Saluran Kemih asimptomatik (ISK) pada perempuan hamil. Membandingkan kesesuaian antara pemeriksaan mikroskopis dan hasil kultur urin sebagai modalitas diagnostik standar emas untuk mendukung diagnosis ISK dan sebagai dasar bukti untuk memulai terapi empiris.
\end{abstract}

Metode : Penelitian uji mikroskopik dilakukan pada 74 sampel urin disentrifugasi dan tidak sentrifugasi, dari 317 sampel urin perempuan hamil yang berobat ke-enam puskesmas di Jakarta dengan uji nitrit positif. Hasil uji mikroskopik bakteri uria dan leukosit uria dibandingkan dengan hasil kultururin.

Hasil:Sensitivitas bakteriuriayang disentrifugasimenunjukan hasil yang paling baik dibandingkan dengan parameter uji mikroskopik lain, yaitu $74 \%$ dengan nilai p yang bermakna sebesar 0,009. Kombinasi bakteriuria dan leukosituria $\geq 3$ / LPB dan $\geq 5 / L P B$ dapat meningkatkan spesifisitas uji dengan nilai $91,5 \%$ dan 93,6\% pada urin yang tidak disentrifugasi.

Kesimpulan : Hasil menunjukkan bahwa bakteri uria pada urin yang disentrifugasi, merupakan metode yang paling baik untuk membantu diagnosis dini ISK tidak bergejala pada perempuan hamil. Uji kombinasi bakteri uria dan leukosituria, serta uji leukosituria $\geq 3 / L P B$ dan $\geq 5 / L P B$ dapat dimanfaatkan untuk membantu secara dini menyingkirkan orang yang tidak mengalami ISK.

Kata kunci : bakteriuria, infeksi saluran kemih tidak bergejala, kultur urin,leukosituria, uji mikroskopik. 


\section{INTRODUCTION}

Urinary Tract Infection (UTI) is the second most prevalent infection in the world, with approximately 8,3 million cases per year. ${ }^{1}$ Urinary tract infection is more prevalent in women than in men. ${ }^{2}$

Urine culture is the gold standard test to diagnose UTI. Urine culture is used to isolate, identify, and quantify pathogen, causing UTI, as well as testing for antibiotics sensitivity. Empiric treatment is essential in pregnant women while waiting for culture results. Delayed treatment may harm the mother and fetus, and results in poor pregnancy outcomes, fetal death, and preterm labor. ${ }^{3}$

Therefore, a rapid screening method is needed to diagnose UTI while awaiting culture results and sensitivity test. A microscopic test is one of the rapid screening alternatives for early diagnosis of UTI. To reduce the possibility of false negatives, it is necessary to centrifuge the urine sample to obtain sediments containing the pathogenic microorganisms. ${ }^{2,3}$ This study aims to compare results of urine microscopic test, with and without centrifugation, and urine culture.

\section{METHODS}

This was a cross-sectional diagnostic study to compare the results of the microscopic test and urine culture to diagnose asymptomatic UTI in pregnant women. A urine sample was collected from pregnant women during prenatal visits in six community healthcare facilities in Jakarta from December 2014 to December 2015. A urine sample was processed in Clinical Microbiology Laboratory, Faculty of Medicine, Universitas Indonesia. We included pregnant women in any trimester who did not consume any antibiotics in the past two weeks and agree to participate in the study. Women with vaginal discharge and fever were excluded. The microscopic test was done in two methods, with centrifugation and without centrifugation of the urine sample, and then Gram staining was conducted. Urine cultures are conducted using blood agar and Mac Conkey agar as a medium in aerobic condition and temperature of $35^{\circ} \mathrm{C}-37^{\circ} \mathrm{C}$ for $24-48$ hour.
Results from microscopic Gram staining were presented as bacteriuria and leukocyturia. Bacteriuria is defined as the finding of bacteria in the urine sample and was presented as positive or negative. Leukocyturia is the finding of leukocytes in the urine sample and is defined as two criteria, $\geq 5$ leukocyte/HPF and $\geq 3$ leukocyte/ HPF. Culture results were presented as negative or positive. Results are considered positive if there is a finding of bacterial colony $\geq 100.000 / \mathrm{mL}$ urine. The results from the microscopic test, both with centrifugation and without centrifugation, were compared to urine culture as sensitivity, specificity, Positive Predictive Value (PPV), and Negative Predictive Value (NPV).

\section{RESULTS}

A total of 74 urine samples were analyzed in microscopic test and urine culture. Urine culture sample resulted in 27 positive culture and 47 negative culture. Results from the microscopic test compared to urine culture are presented in Table 1. Calculated results of sensitivity, specificity, PPV, and NPV of microscopic tests are presented in Table 1.

Table 1. Sensitivity, Specificity, Positive Predictive Value, and Negative Predictive Value of Microscopic Tests

\begin{tabular}{lcccc}
\hline & $\begin{array}{c}\text { Sensitivity } \\
\%\end{array}$ & $\begin{array}{c}\text { Specificity } \\
\%\end{array}$ & $\begin{array}{c}\text { PPV } \\
\%\end{array}$ & $\begin{array}{c}\text { NPV } \\
\%\end{array}$ \\
\hline Bacteriuria & & & & \\
$\begin{array}{l}\text { Without centrifugation } \\
\text { With centrifugation }\end{array}$ & 63 & 78.7 & 63 & 78.7 \\
$\begin{array}{l}\text { Leukocyturia } \mathbf{3} \text { /HPF } \\
\text { Without centrifugation }\end{array}$ & 3.7 & 57.4 & 50 & 79.4 \\
$\begin{array}{l}\text { With centrifugation } \\
\begin{array}{l}\text { Leukocyturia > 5/HPF } \\
\text { Without centrifugation }\end{array}\end{array}$ & 7.4 & 81.5 & 20 & 62.3 \\
\begin{tabular}{l} 
With centrifugation \\
\hline
\end{tabular} & 3.7 & 93.1 & 22.2 & 61.5 \\
\hline
\end{tabular}

Combined diagnostic results from bacteriuria, leukocyturia $\geq 3 / \mathrm{HPF}$, and leukocyturia $\geq 5 / \mathrm{HPF}$ are presented in Table 3. Calculated results of sensitivity, specificity, PPV, and NPV from combined diagnostic results of three microscopic tests are presented in Table 2. 
Table 2. Sensitivity, Specificity, Positive Predictive Value, and Negative Predictive Value of Combined Microscopic Tests

\begin{tabular}{|c|c|c|c|c|}
\hline & $\begin{array}{c}\text { Sensitivity } \\
\%\end{array}$ & $\begin{array}{l}\text { Specificity } \\
\%\end{array}$ & $\begin{array}{c}\text { PPV } \\
\%\end{array}$ & $\begin{array}{c}\text { NPV } \\
\%\end{array}$ \\
\hline \multicolumn{5}{|l|}{$\begin{array}{l}\text { Positive bacteriuria and } \\
\text { leukocyturia } \geq 3 / \mathrm{HPF}\end{array}$} \\
\hline Without centrifugation & 0 & 91.5 & 0 & 61.4 \\
\hline $\begin{array}{l}\text { With centrifugation } \\
\text { Positive bacteriuria anc } \\
\text { leukocyturia }>5 / \text { HPF }\end{array}$ & 7.4 & 85.1 & 2.2 & 61.5 \\
\hline Without centrifugation & 0 & 93.6 & 0 & 70 \\
\hline With centrifugation & 3.7 & 87.2 & 14.3 & 61.2 \\
\hline
\end{tabular}

Early diagnosis relies on a high sensitivity test. Therefore, Table 3 presents the microscopic tests with the highest sensitivity from each criterion.

Table 3. Microscopic Tests with High Sensitivity

\begin{tabular}{lcccc}
\hline & $\begin{array}{c}\text { Sensitivity } \\
\%\end{array}$ & $\begin{array}{c}\text { Specificity } \\
\%\end{array}$ & $\begin{array}{c}\text { PPV } \\
\%\end{array}$ & $\begin{array}{c}\text { NPV } \\
\%\end{array}$ \\
\hline $\begin{array}{l}\text { Positive bacteriuriawith } \\
\text { centrifugation }\end{array}$ & 74 & 57.4 & 50 & 79.4 \\
$\begin{array}{l}\text { Leukocyturia } \geq 3 / \text { HPFwith } \\
\text { centrifugation }\end{array}$ & 7.4 & 85.1 & 22.2 & 61.5 \\
$\begin{array}{l}\text { Leukocyteuria> 5/HPF } \\
\text { without centrifugation }\end{array}$ & 3.7 & 93.6 & 25 & 62.9 \\
$\begin{array}{l}\text { Positive bacteriuria and } \\
\text { Leukocyturia } 2 \text { 3/HPF with }\end{array}$ & 7.4 & 85.1 & 22.2 & 61.5 \\
$\begin{array}{l}\text { centrifugation } \\
\begin{array}{l}\text { Positive bacteriuria and } \\
\text { Leukocyteuria> 5 /LPB }\end{array}\end{array}$ & 3.7 & 87.2 & 14.3 & 61.2 \\
\begin{tabular}{l} 
with centrifugation \\
\hline
\end{tabular} & & & & \\
\hline
\end{tabular}

\section{DISCUSSION}

\section{Bacteriuria Compared with Urine Culture Outcomes}

Assessment of bacteriuria in microscopic examination of this study was conducted based on the presence of bacterial findings, Gram staining procedure, and bacterial morphology found. The results are then matched with the urine culture results, which showed the number of correspondence was lower in non-centrifuged urine samples than in centrifuged urine, with a sensitivity of $63 \%(17 / 27)$ versus $74 \%(20 / 27)$. These results showed that the centrifuged urine gives better microscopic test results of bacteriuria finding than the non-centrifuged urine. This value is lower than in a previous study conducted by Wilson et al in Colorado, who obtained sensitivity values for centrifuged urine bacteriuria of 92$100 \%$ and with the sensitivity value of $89 \% .{ }^{4,5}$

In this study, Gram staining results and the morphology of bacteria species findings derived from urine culture correspond well. In this case, better results were also shown in centrifuged urine bacteriuria compared with non-centrifuged urine, by $95 \%(19 / 20)$ versus $88.2 \%$ (15/17) sensitivity. This better results may be caused by cellular elements and other components of biological fluid as well as bacteria being more concentrated as a result of centrifugation. ${ }^{6}$

Viewed from the specificity value, compared with the urine culture results, the bacteriuria of the non-centrifuged urine sample is preferable to the specificity of the centrifuged urine, which is $78.7 \%$ versus $57.4 \%$. The value falls within the range of specificity values found in a study conducted by Wilson et al which attained an 8-94\% specificity value for bacteriuria in centrifuged urine. ${ }^{4}$ The results of this study were slightly lower when compared with a previous study conducted with the specificity value of $85 \% .^{5}$

Leukocyturia compared with Urine Culture Outcomes Leukocyturia an interpretative result of microscopic tests which was assessed based on the number of leukocytes contained in the urine. Leukocyturia in this study used two threshold values of leukocyturia $\geq 3 / \mathrm{HPF}$, which is recommended by CDC and leukocyturia $>5$ / HPF, which were used by some previous studies. ${ }^{7}$ The sensitivity of leukocyturia $\geq 3$ /HPF found in the Gram staining microscopic test compared with the results of urine culture, which gave significant results with the amount of $\geq 100,000$ $\mathrm{CFU} / \mathrm{mL}$ colonies, had shown low results in both centrifuged or non-centrifuged urine. The sensitivity of leukocyturia $\geq 3 / \mathrm{HPF}$ compared to urine culture found in centrifuged and noncentrifuged urine samples are of $7.4 \%$ and $3.7 \%$ value. These results showed that leukocyturia $\geq 3$ / HPF found in centrifuged and non-centrifuged urine microscopic tests are less likely to be used as an alternative for early diagnosis of asymptomatic UTI in pregnant women. However, the results of leukocyturia $\geq 3 / \mathrm{HPF}$ specificity compared with urine culture were better in both treatment types, which were $91.5 \%$ in non-centrifuged urine samples and $85.1 \%$ in centrifuged urine.

The sensitivity of leukocyturia $>5 / \mathrm{HPF}$ in both urine samples compared with culture results had shown a similar value of $3.7 \%$. However, compared with urine culture, the specificity value of leukosituria>5/ LPB in non-centrifuged was higher than centrifuged urine, with specificity 
values of $93.6 \%$ and $87.2 \%$, respectively. Regarding the detection of leukocyturia found in microscopic tests aiming for early diagnosis of asymptomatic UTI, the low sensitivity value of leukosituria $>5$ / LPB illustrates that this value is also less suitable for both centrifuged and noncentrifuged urine samples.

\section{Combination of Bacteriuria and Leukocyturia in Urine Microscopic Test Compared with Results of Urine Culture}

The assessment of the compatibility of combinations of bacteriuria and leukocyturia found in urine microscopic tests compared with urine culture results aimed at increasing the sensitivity of microscopic tests in the early diagnosis of asymptomatic UTI. The combination of bacteriuria and leukocyturia $\geq 3 / \mathrm{HPF}$ in centrifuged urine had a slightly higher sensitivity value than non-centrifuged urine, i.e. $7.4 \%$ versus $0 \%$. Similar results were also found in the sensitivity of bacteriuria and leukocyturia $>5$ / HPF, which showed a slightly higher centrifuged urine sensitivity than non-centrifuged urine of $3.7 \%$ compared to $0 \%$. These results indicate that the combination of both bacteriuria and leukocyturia with leukocyturia $\geq 3 / \mathrm{HPF}$ as recommended by $C D C$ or in combination with leukocyturia > 5/HPF according to some previous studies, is no better than bacteriuria alone. However, the combination of bacteriuria and leukocyturia gave excellent results in specificity value, both in the non-centrifuged urine and in the centrifuged urine. The specificity value of the combination of bacteriuria and leukocyturia $\geq 3$ / HPF in non-centrifuged and centrifuged urine samples are $91.5 \%$ and $85.1 \%$, respectively. The specificity value of bacteriuria and leukocyturia combination $>5 / \mathrm{HPF}$ is $93.6 \%$ in non-centrifuged and $87.2 \%$ in centrifuged urine samples. Based on these results, the combination of bacteriuria and leukocyturia is more appropriate for use to exclude instead of to support early diagnosis of asymptomatic UTI in pregnant women.

\section{The Best Urine Microscopic Test Method for Early Diagnosis asymptomatic UTI in Pregnant Women}

The highest sensitivity value is a reference for the selection of diagnostic tests for early diagnosis of a disease. In this study, the use of microscopic test of urine samples with various methods was compared with the results of urine culture as a gold standard. ${ }^{8}$ Detection of bacteriuria alone in the microscopic urine test obtained in this study, provided the best sensitivity results for use as early diagnosis of asymptomatic UTI in pregnant women, especially when examined from centrifuged urine. ${ }^{8-10}$ Statistical analysis using the chi-square test showed a significant $p$-value of 0.009 .

Other parameters are insufficient for use as an early diagnostic tool of asymptomatic UTI in pregnant women, either from a leukocyturia sensitivity alone or a combination of bacteriuria and leukocyturia. The analysis for the significance of these results used the Fischer test because it did not qualify for the chi-square test. The sensitivity value of leukocyturia $\geq 3 / \mathrm{HPF}$ according to the recommendation of CDC was better in centrifuged urine samples (7.4\%), but the result of statistical analysis did not show a significance, with a $p$-value of 0.472 . In leukocyturia with parameter $>5 / \mathrm{HPF}$ according to some previous studies, better sensitivity value in non-centrifuged urine was 3.7\%, but the result of analysis also did not show significance with $p=$ 1. Analysis of the combination of bacteriuria with leukocyturia $\geq 3 / \mathrm{HPF}$ showed better sensitivity results in centrifuged urine, with a sensitivity value of $7.4 \%$, and a non-significant $p$-value of 0.472 . Analysis of the combination of bacteriuria with leukocyturia $>5 / \mathrm{HPF}$ showed better sensitivity results in centrifuged urine, with a sensitivity of $3.7 \%$ and a non-significant $p$-value of 0.411 .

Based on the above data, it can be understood that bacteriuria alone is the best urine microscopic test method for early diagnosis of asymptomatic UTI in pregnant women. ${ }^{11,12}$ The use of combination parameters of bacteriuria and leukocyturia did not increase sensitivity but rather increased the specificity of the test. The results of good test specificity on the resultant combinations of bacteriuria and leukocyturia in non-centrifuged urine microscopic tests were as good as the specificity of leukocyturia alone, for both cutoffs of $\geq 3 / \mathrm{HPF}$ and $>5 / \mathrm{HPF} .{ }^{13}$ This results showed that microscopic testing of combination of bacteriuria and leukocyturia or leukocyturia alone could be used to help exclude the diagnosis of asymptomatic UTI in pregnant women. 


\section{CONCLUSION}

The detection of bacteriuria alone in centrifuged urine is the best urine microscopic test method to assist early diagnosis of asymptomatic UTI in pregnant women. However, the combination test of bacteriuria and leukocyturia, as well as leukocyturia alone in both centrifuged and noncentrifuged urine can help rid of early diagnosis of asymptomatic UTI in pregnant women.

The discovery in this study should be used as an alternative to urine culture, to aid early diagnosis of asymptomatic UTI in pregnant women, thus serving as a guide to starting earlier empirical therapy to prevent complications that endanger the mother and the fetus.

\section{ACKNOWLEDGEMENT AND AFFILIATION}

This study was supported by Zambon Indonesia. We thank the team from ObstetricGynecologic Department FMUI-RSCM and Clinical Microbiology Laboratory, Microbiology Department FMUI-RSCM for supporting and collaborating in this study. We also would like to thank the senior medical students of FMUI, batch of 2010 enrolled in Obstetric-Gynecologic rotation at the time for helping collect the urine samples for this study.

\section{REFERENCES}

1. Tessy A, Ardayo, Suwanto. Infeksi Saluran Kemih. Buku Ajar Ilmu Penyakit Dalam Jilid III. 4th Ed. Jakarta: Balai Penerbit FKUI; 2009:369.

2. Sukandar E. Infeksi Saluran Kemih pada Pasien Dewasa. Buku Ajar Ilmu Penyakit Dalam Jilid III. 4th Ed. Jakarta: Balai PenerbitFKUI;2007:553-7.

3. Awonuga DO, Fawole AO, Dada-Adegbola HO, Olola FA, Awonuga OM. Asymptomatic bacteriuria in pregnancy: evaluation of re-agent strips in comparison to microbiological culture. Afr J Med Sci. 2011; 40(4): 377-83.

4. Wilson ML, Gaido L. Laboratory diagnosis of urinary tract infections in adult patients. Clin Infect Dis. 2004;38(8):1150-8.

5. Lunn A, Holden S, Boswell T. Automated microscopy, dipsticks and the diagnosis of urinary tract infection. Arch Dis Child. 2010;95(3):193-7

6. Ocviyanti D, Fernando D. Tata Laksana dan Pencegahan Infeksi Saluran Kemih pada Kehamilan. Indones Med Assoc 2012; 62(12): 483.

7. Paolo G, Vijaya BR, Odile D, Daniel J. Ureter, Urinary Bladder, and Kidney. 3rd Ed. Philadelphia: Elsevier Saunders; 2010:515-20.

8. Burd EM, Kehl KS. A Critical appraisal of the role of the clinical microbiology laboratory in the diagnosis of urinary tract infections. J Clin Microbiol. 2011; 49(9):81534.

9. Jeff AS, William CM, John JP. Urinalysis: A comprehensive review. Am Fam Physician. 2005; 71(6):1153-62.

10. Alastair DH. Managing UTI in primary care: Should we be sending midstream urine samples? Br J Gen Pract. 2010; 60(576): 479-80.

11. Thairu Y, Nasir IA, Usman Y. Laboratory perspective of gram staining and its significance in investigations of infectious diseases. Sub-Saharan Afr J Med 2014;1:16874.

12. Memisogullan $R$, Yuksel $H$, Yildirim $H A$, Yavuz $O$. Performance Characteristics of dipstick and microscopic urinalysis for diagnosis of urinary tract infection. Eur J Gen Med. 2010;7(2):174-8.

13. Kurup R, Leich M. Comparison of urine analysis using manual and sedimentation methods. J West Ind Med.2012; 61(3):17-9 